\title{
SNPs in DNA repair or oxidative stress genes and late subcutaneous fibrosis in patients following single shot partial breast irradiation
}

\author{
Elisabetta Falvo ${ }^{1 *}$, Lidia Strigari ${ }^{2}$, Gennaro Citro ${ }^{1}$, Carolina Giordano ${ }^{3}$, Genoveva Boboc ${ }^{3}$, Fabiana Fabretti ${ }^{3}$, \\ Vicente Bruzzaniti ${ }^{2}$, Luca Bellesi ${ }^{2}$, Paola Muti ${ }^{4,5}$, Giovanni Blandino ${ }^{6}$ and Paola Pinnarò ${ }^{3}$
}

\begin{abstract}
Background: The aim of this study was to evaluate the potential association between single nucleotide polymorphisms related response to radiotherapy injury, such as genes related to DNA repair or enzymes involved in anti-oxidative activities. The paper aims to identify marker genes able to predict an increased risk of late toxicity studying our group of patients who underwent a Single Shot 3D-CRT PBI (SSPBI) after BCS (breast conserving surgery).
\end{abstract}

Methods: A total of 57 breast cancer patients who underwent SSPBI were genotyped for SNPs (single nucleotide polymorphisms) in XRCC1, XRCC3, GST and RAD51 by Pyrosequencing technology. Univariate analysis (ORs and 95\% CI) was performed to correlate SNPs with the risk of developing $\geq$ G2 fibrosis or fat necrosis.

Results: A higher significant risk of developing $\geq \mathrm{G} 2$ fibrosis or fat necrosis in patients with: polymorphic variant GSTP1 (lle105Val) (OR = 2.9; 95\%Cl, 0.88-10.14, $p=0.047$ ).

Conclusions: The presence of some SNPs involved in DNA repair or response to oxidative stress seem to be able to predict late toxicity.

Trial Registration: ClinicalTrials.gov: NCT01316328

Keywords: Radiotherapy, Breast cancer, Polymorphisms, Late effects, Fibrosis

\section{Background}

Conservative surgery followed by adjuvant radiotherapy (RT) to whole breast has become widely accepted as a standard of care for women with early breast cancer. In particular, a number of studies [1-4] reported that most (81\%-100\%) intra breast tumour recurrences after breast conserving surgery (BCS) occur in close proximity to the tumour bed, so providing the rationale of Partial Breast Irradiation (PBI) an adjuvant RT limited to the Index Area i.e. the area of breast only including the primary tumour bed and the surrounding tissue. In addition, the delivery of radiation dose to smaller target volume by $\mathrm{PBI}$ is expected to reduce radiation-related toxicity. Thus, the so-called Accelerated Partial Breast

\footnotetext{
* Correspondence: falvo@ifo.it

'Laboratory of Pharmacokinetic/Pharmacogenomic, Regina Elena National Cancer Institute, Rome, Italy

Full list of author information is available at the end of the article
}

Irradiation (APBI), where only the Index Area is irradiated in 1-10 fractions at high dose/fraction, has been promoted in phase I-III trials designed to test feasibility and equivalence with standard Whole Breast Irradiation (WBI) in properly selected low risk early breast cancer patients after BCS [5]. However, a remarkably high rate of late toxicity has been reported by some Authors a few years after follow up with this APBI approach [6,7]. A high late toxicity rate was also observed in our cohort, after single shot of PBI (SSPBI) [8]. Thus the possibility to predict patient outcome based on marker genes correlated with radio-induced toxicity was investigated.

The interaction of RT with living tissue generates, directly or transitorily, reactive oxygen species (ROS) triggering a series of inflammation reactions. Adaptation to oxidative stress occurs by activating genes that characterize the cellular responses to this type of stress and generates a series of processes including DNA repair

\section{Biomed Central}

(c) 2012 Falvo et al; licensee BioMed Central Ltd. This is an Open Access article distributed under the terms of the Creative Commons Attribution License (http://creativecommons.org/licenses/by/2.0), which permits unrestricted use, distribution, and reproduction in any medium, provided the original work is properly cited. 
pathways, cell cycle arrest, antioxidant enzymes and secretion of cytokines that are suspected to play a central role in the development of mainly late normal tissue damage $[9,10]$. These mechanisms, eventually lead to avoiding extensive DNA damage, cell death [11], and inflammatory process, that may enhance ROS production, thus, contributing to the formation of fibrogenesis and tissue remodelling [12]. In particular, Glutathione$S$-Transferase (GSTs) are antioxidant enzymes which are classified into the following classes: alpha (GSTA), mu (GSTM), pi (GSTP), theta, sigma, and kappa. Under conditions of stress the GSTP1 class is implicated in proapoptotic signalling and may mediate cytotoxicity [13-15]. Two independent studies recently carried out on $\mathrm{BC}$ patients have reported a significant association between the GSTP1 $105 \mathrm{Val}$ variant (313 G) and an increased risk of developing acute or late adverse reactions induced by radiation therapy $[9,16]$.

In addition, XRCC1 (X-ray Repair Cross-Complementation group 1), XRCC3 (X-ray Repair Cross-Complementation group 3) RAD51, genes involved in the DNA repair process may influence susceptibility to side effects in patients receiving radiation therapy given that DNA is a direct target for ionizing radiation [17-20].

Various studies [21-23] showed a significant association between the polymorphic nature of these genes and the possibility of developing biomarkers or predictive assay for radio-sensitivity in breast cancer patients.

To correlate the genetic variation and association between the development of late effects [24,25], we investigated the following specific polymorphic genes: XRCC1 (Arg399Gln), XRCC3 (5'UTR and Thr241Met), GSTP1 (Ile105Val) and RAD51.

\section{Methods}

From March 2006 to January 2008, patients who underwent BCS and a sentinel node biopsy and/or axillary dissection for early breast adenocarcinoma and met eligibility criteria were treated in the prone position with an adjuvant single dose 3D-CRT APBI schedule to the Index Area. The eligibility criteria included being aged $\geq$ 48 years with a life expectancy of at least 5 years, postmenopausal status, histologically proved cancer, non lobular, adenocarcinoma of the breast, primary tumours $\leq 3 \mathrm{~cm}$, negative surgical margins $(\geq 2 \mathrm{~mm})$, negative sentinel nodes or $<4$ positive axillary nodes, no extracapsular extension, no previous radiotherapy. The exclusion criteria included patients with multicentric disease, extended intraductal component (EIC > 25\%), Paget's disease of the nipple, lobular adenocarcinoma, and distant metastases.

A dose of 18 (in 4 patients) or 21 Gy (in 60 patients), normalized to the PTV mean dose, was prescribed in a single session. Major technical details of our approach have been previously reported in detail in a distinct paper [26]. Some radiobiological considerations on single dose, time factors, clonogenic cell density and dose constraints are reported in distinct papers [27-30].The study was conducted in accordance with the Helsinki Declaration. Each patient was informed about the study protocol in both verbally and in writing (informed consent) in advance. The patient was given ample opportunity to request relevant information regarding the study and decide on their own whether to participate in the protocol. The protocol was approved by the local Ethics and Scientific Committee of the Regina Elena Italian National Cancer Institute (reference number IFO-84/ 10). (The trial has been registered at the ClinicalTrials. gov website and it is identified as NCT01316328).

Fibrosis was assessed using the National Cancer Institute's Common Terminology Criteria for Adverse Events (CTCAE, version 3.0) [31]. Fat necrosis was also scored according to the system proposed by Lövely et al. [32]. The end-point of this study is Grade 2 or more fibrosis or fat necrosis. Toxicity was defined as late if it occurred $\geq 6$ months after radiotherapy.

All subjects enrolled in the study provided a blood sample, approximately $5 \mathrm{ml}$, in sterile tubes containing ethylenediaminetetracetic acid (EDTA). Whole blood samples for DNA analyses were immediately frozen at $-80^{\circ} \mathrm{C}$ until processing. Total genomic DNA of samples was extracted from blood leukocytes using the kit QIAmp (DNA blood Mini Kit, Qiagen, Valencia, CA) following the manufacturer's instructions. DNA quality was evaluated by spectrophotometer analysis (NanoDrop instrument). PCR reactions for these polymorphic genes were performed as Real Time PCR using Rotorgene Instrument (Corbett) following PCR (Polymerase Chain Reaction) conditions provided by the manufacturer's instructions. The polymorphic genes: XRCC3 C18067T (Thr241Met), XRCC3 A4541G (5'-UTR untranslated region), XRCC1 G28152A (Arg399Gln), GSTP1 A313G (Ile105Val) RAD51 G135C (untranslated region including in the commercial kits for Radiotherapy Response) (Diatech company) were evaluated. The polymorphic genes were analyzed using Pyrosequencing technologies (instrument PyroMark MD-Biotage, Uppsala, Sweden) according to a previously published method [33].

The first step of the study was designed to correlate SNPs of genes and acute effects (i.e. erythema) [34]. We assumed an erythema rate of $20 \%$ and $54 \%$ in patient groups at low and high risk, respectively, (groups were identified based on the absence/presence of the above polymorphisms alone or in combination). Thus the minimum sample size was 56 patients with $\alpha=0.05$, 2tailed test and a power of the study of $80 \%$. More radiosensitive patients are expected to show an increased number of acute, as well as, late effects. Thus, we also 
decided to investigate in a second step the late fibrosis/ fat necrosis and the following polymorphisms: XRCC3 C18067T (Thr241Met), XRCC3 A4541G (5'-UTR), XRCC1 G28152A (Arg399Gln), GSTP1 A313G (Ile105Val) and RAD51 G135C (untranslated region). Moreover, we also analyzed combined genotypes according to data from literature.

Tests for statistical significance were performed with the chi-square and $t$-test for categorical and continuous variables, respectively. Odds ratios (ORs) and 95\% confidence intervals (CIs), Chi-squared and Fisher exact (2sided) tests were calculated. An OR $>1.0$ indicates an increased risk of fibrosis in patients with polymorphic gene. All tests were two-sided and considered to be statistically significant with a $p$-value of $p=0.05$.

\section{Results}

To these study purposes, i.e. determining polymorphisms predicting late toxicity, we recruited 57 patients treated with SSPBI from March 2006 to January 2008. Out of 57 patients, 15 (26\%) were also treated with adjuvant non-concomitant chemotherapy. The adjuvant chemotherapy had been completed 3-4 weeks before RT with the exception of one patient (underwent chemotherapy one-week after SSAPBI). Adjuvant hormonotherapy, as indicated, was given simultaneously with SSPBI. Patient, tumour and treatment related characteristics are listed in Table 1, respectively. In Table 2, we reported the abbreviations for the polymorphic sites. The genotyping procedure was successful in 57 patients. The observed allele frequencies of the polymorphic genes analyzed were comparable to those reported for European populations in the dbSNP database and are shown in Figure 1.

With a median follow-up 38 months (range: 19-50 months), the G1, G2 and G3 subcutaneous fibrosis, corresponding to a marked increased density and firmness on palpation with/without retraction/fixation, were observed in 23 (40\%), 18 (32\%) and 7 (12\%) patients, respectively. While the G2 and G3 fat necrosis were observed in $1(2 \%)$ and $1(2 \%)$ patient, respectively.

Late moderate-to-severe ( $\geq$ G2) subcutaneous fibrosis or fat necrosis were more frequent (64\% vs 38\%) in patients with the mutation or heterozygote $(\mathrm{aa} / \mathrm{Aa})$

\section{Table 1 Main patient and tumor characteristics}

\begin{tabular}{llc}
\hline Age (years) & median (range) & $66(51-87)$ \\
Tumor stage & Tis/T1/T2 & $1 / 48 / 8$ \\
Nodal stage & No/N1 & $54 / 3$ \\
Chemotherapy & yes/no & $15 / 42$ \\
Hormone-therapy & yes/no & $52 / 5$ \\
Follow-up (months) & median (range) & $38(19-50)$ \\
\hline
\end{tabular}

genotype of GSTP1 (Ile105Val) with greater odds (OR = 2.9; 95\% CI, 0.88-10.14, $p=0.047$ Chi-square test).

No statistical significant increase/decrease of ORs was observed with other SNPs or their combination. In particular, no correlation was found between late toxicity and mut/het XRCC1 Arg399Gln, mut/het XRCC3 A $4541 \mathrm{G}$ or mut/het XRCC3 Thr241Met or mut/het $R A D 51$. Table 3 shows a summary of a statistical analysis.

Forest plots of $\geq \mathrm{G} 2$ fibrosis or fat necrosis in breast cancer patients against het/mut GSTP1 and XRCC1 Arg399Gln are shown in Figures 2 and 3, respectively, reporting a meta-analysis of data available from literature.

\section{Discussion}

Recently partial breast irradiation has been proposed in a particular subgroup of patients at low risk of local recurrence. In agreement with this approach, we tested a new schedule at our Institute naming it SSPBI after BCS $[8,28]$. Due to the major expected killing efficacy of the single dose, unfortunately a incidence of fibrosis/fat necrosis was observed in $44 \%$ of our patients.

Generally the moderate-to-severe fibrosis after conventional fractionation is generally observed in $13.5 \%$ [35] of patients at 10 years; thus a lot of patients to obverse the same number of complications observed in our cohort (44\%). Moreover, the single dose is expected to be more difficult to be repaired, enhancing the scenarios in which the mechanism of protect against $R O S$ damage or DNA repair fails.

It is for this reason, we focused our attention on SNPs evaluation that may help design a clinical approach and explain basic phenomena such as subcutaneous fibrosis or fat necrosis. Fibrosis is a complex tissue response characterized by a massive deposition of extra cellular matrix $(E C M)$ molecules (collagens, non collagenous glycoproteins, glycosaminoglycans, proteoglycans) and excessive fibroblast proliferation. Under oxidative stress generated by ionization radiation, ROS levels can increase dramatically, and this may result in significant damage to cell structures. Accordingly, in the cellular compartments, the response to oxidative stress can activate a series of processes including DNA repair, antioxidant enzymes, cell cycle arrest and secretion of proinflammatory cytokines such as TNF- $\alpha, T G F-\beta 1, I L 1$, IL6 and many growth factors in the irradiated tissue. Some authors reported that a coordinated cellular response after radiation occurs, like the involvement antioxidant enzymes (such as superoxide dismutases, catalases, lactoperoxidases, glutathione peroxidases and peroxiredoxins) to protect themselves against ROS damage [11-13].

Reduced mechanisms of cell protection resulting from functional polymorphisms in several genes involved in 
Table 2 Polymorphism abbreviations

\begin{tabular}{lllll}
\hline Gene & $\begin{array}{l}\text { NCBI } \\
\text { ds SNP ID }\end{array}$ & homozygote wt & heterozygote & Homozygote mut \\
\hline XRCC1 G28152A (Arg399GIn) & rs25487 & GG (399 Arg/Arg) & GA(399Arg/Gln) & AA (399 Gln/Gln) \\
\hline XRCC3 C18067T (Thr241Met) & rs861539 & CC (241Thr/Thr) & CT(241Thr/Met) & T (241Met/Met) \\
\hline XRCC3 A4541G (5'UTR) & rs1799794 & AA & AG & GG \\
\hline GSTP1A313G (Ile105Val) & rs1695 & AA (105 Ile/lle) & AG (105 Ile/Nal) & GG (105 Val/Nal) \\
\hline RAD51 G135C (5'UTR) & rs1801320 & GG & GC & CC \\
\hline
\end{tabular}

Abbreviations: $N C B I$ = National Center for Biotechnology Information, ID = identification

these processes may be associated with the development of late side effects following RT [36]. For these reasons, we decided to investigate genetic variation in enzymes involved in the detoxification process of oxidative stress products, such as GSTP1, and its possible correlation with susceptibility to late complications after RT [37,38].

In particular, we found that the polymorphic variant (aa, Aa) of GSTP1 (Ile105 Val), producing a protein with reduced activity, is associated with higher risk of developing (G2 or more) a fibrosis or fat necrosis. In fact, Forest plot shows behaviour as toxic agent for GSTP1.

The role of GSTP1 is debated in literature for example Zschenker et al.[39] reported a no statistically significant reduction in G2/G3 fibrosis (like-protective), Kuptsova et al.[40], also in analyzing breast cancer patients found no difference for fibrosis due to the relative small number of patients with this side effect. While Edvardsen et al. [9] reported no association with fibrosis but with an enhanced risk of pleural thickening (like-toxic).
In exacting, GSTP1 is involved in the regulation of cell proliferation, apoptosis, stress response, phase II metabolism, oncogenesis, tumour progression and drug resistance. A number of recent studies [11-13] support the role of GSTP1 in cell cycle control through the regulation of c-Jun amino-terminal kinase (JNK) and its indirect role in cellular signalling with interaction with cellular proteins: TNF- $\alpha$, TRAF2 cytochine, transcription factor response gene AP-1.

As shown in Figure 4, under no stress condition GSTP1 interacts with c-Jun amino-terminal kinases (JNKS) and represses their activity. After treatment with $\mathrm{RT}$, the concentration of ROS in the cell increase and causes the dissociation of GSTP1-JNK complex through the oligomerization of GSTP1 from monomer to dimer. Subsequently, the released JNK kinase recovers its functional activity and can be phosphorylated and phosphorylate $c$-jun. The consequent phosphorylation of $c$-jun activates the transcription of $A P-1$ (stress responsive

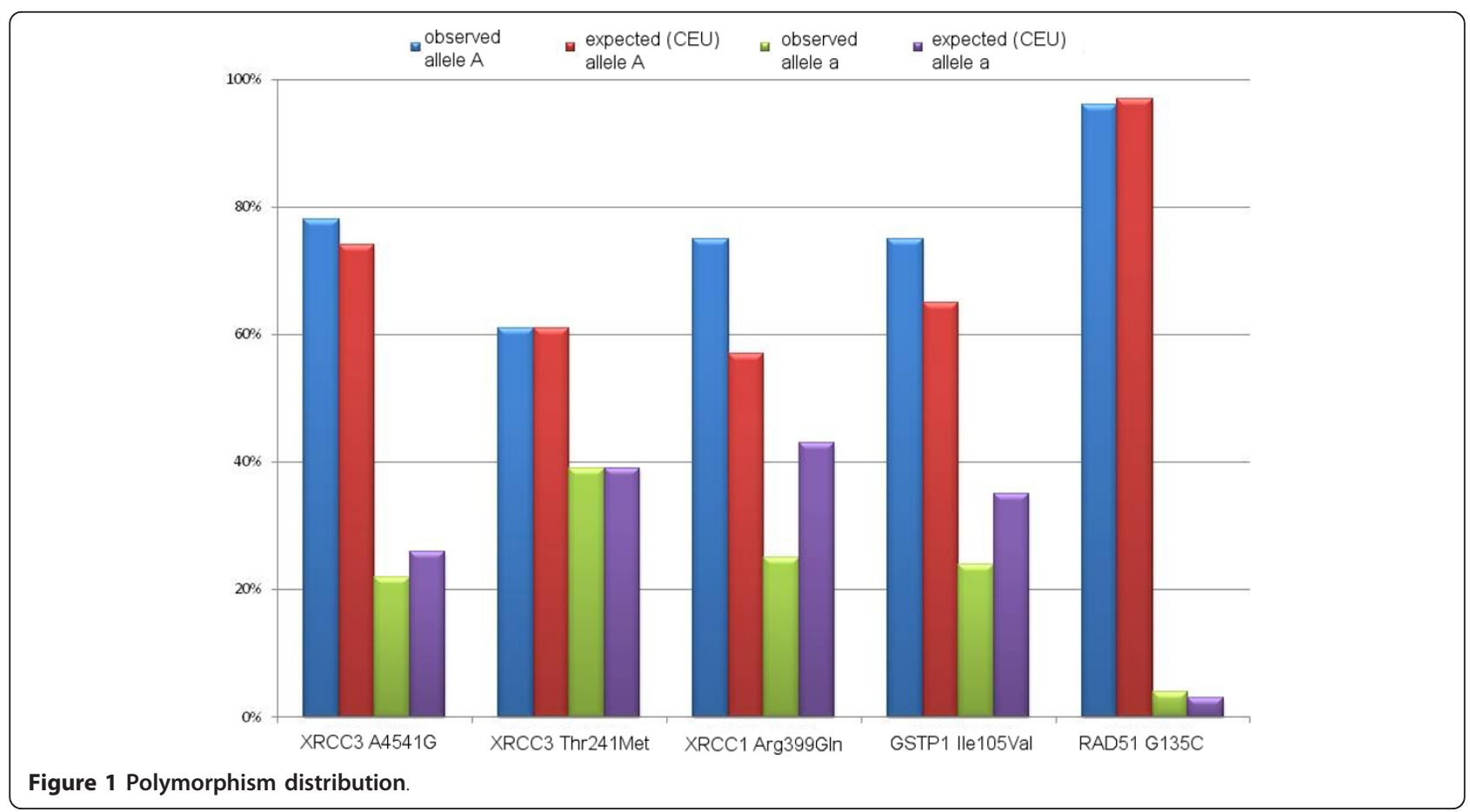


Table 3 ORs of $\geq$ G2 fibrosis or fat necrosis for different polymorphisms and their combination

\begin{tabular}{|c|c|c|c|c|c|}
\hline Polymorphisms & Genotype & $\begin{array}{c}\geq \text { G2 fibrosis } \\
\text { or fat } \\
\text { necrosis }\end{array}$ & $\begin{array}{c}\text { OR } \\
(95 \% \mathrm{Cl})\end{array}$ & $p$-value $(*)$ & $p$-value (§) \\
\hline \multirow[t]{2}{*}{ XRCC1 (Arg399GIn) } & AA & $45 \%$ & 1 & & \\
\hline & $\mathrm{aa} / \mathrm{Aa}$ & $54 \%$ & $1.41(0.44-4.58)$ & 0.514 & 0.599 \\
\hline \multirow[t]{2}{*}{ XRCC3(A4541G) } & $\mathrm{aa} / \mathrm{Aa}$ & $44 \%$ & 1 & & \\
\hline & AA & $53 \%$ & $1.43(0.45-4.71)$ & 0.494 & 0.596 \\
\hline \multirow[t]{2}{*}{ XRCC3(C18067T) } & $\mathrm{AA} / \mathrm{Aa}$ & $51 \%$ & 1 & & \\
\hline & aа & $33 \%$ & $0.49(0.04-3.75)$ & 0.413 & 0.670 \\
\hline \multirow[t]{2}{*}{ GSTP1 } & AA & $38 \%$ & 1 & & \\
\hline & $\mathrm{aa} / \mathrm{Aa}$ & $64 \%$ & $2.9(0.88-10.14)$ & 0.047 & 0.064 \\
\hline \multirow[t]{2}{*}{ RAD51 } & AA & $48 \%$ & 1 & & \\
\hline & $\mathrm{aa} / \mathrm{Aa}$ & $67 \%$ & NA \# & 0.9751 & 0.6115 \\
\hline
\end{tabular}

Abbreviations: (*) Chi-squared, (§) Fisher's exact Test, \#: not applicable due to the limited number of events

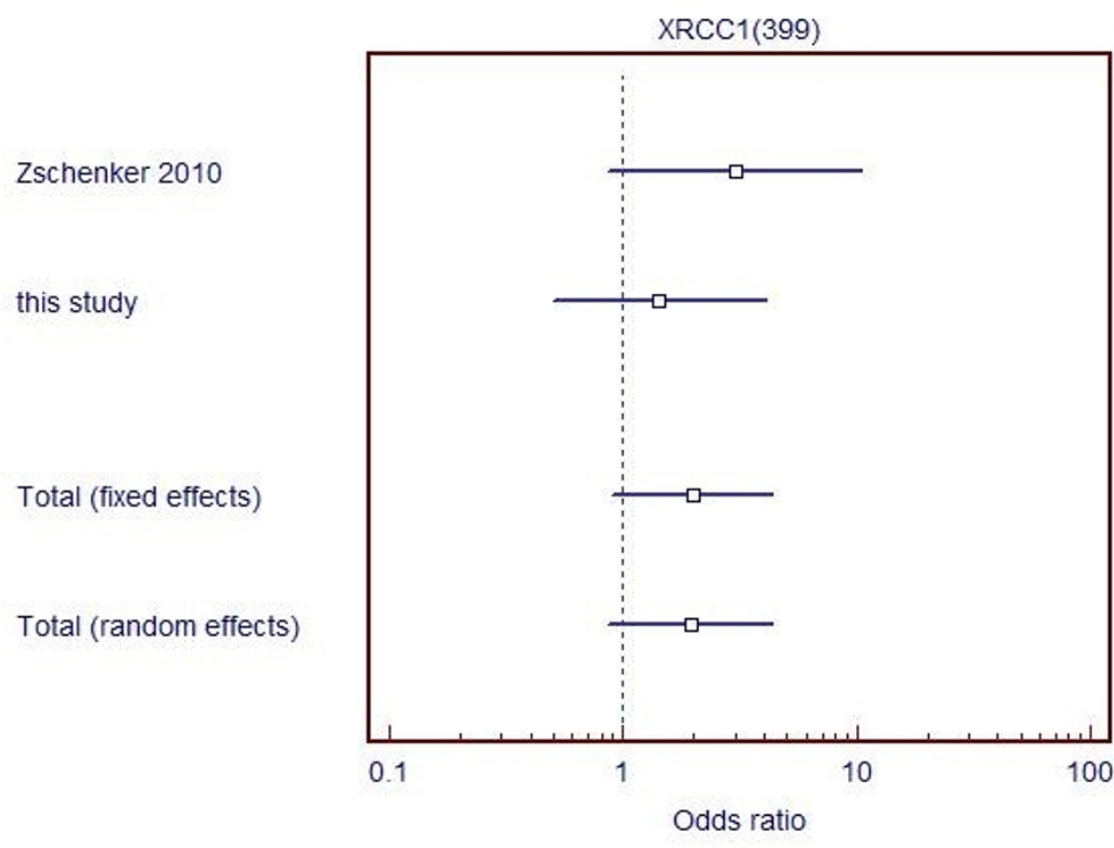

Study Intervention Controls Odds $95 \% \mathrm{Cl}$

\begin{tabular}{llllll}
\hline Zschenker 2010 & $13 / 40$ & $4 / 29$ & 3.009 & 0.866 & 10.459 \\
this study & $14 / 26$ & $14 / 31$ & 1.417 & 0.498 & 4.034 \\
& & & & & \\
Total(fixed effects) & $27 / 66$ & $18 / 60$ & 1.969 & 0.895 & 4.333 \\
Total (random effects) & $27 / 66$ & $18 / 60$ & 1.935 & 0.868 & 4.311
\end{tabular}

Test for heterogeneity

$Q=0.8257, D F=1, P=0.3635$

Figure 2 Forest plot summarizes a pooled analysis of G2 or more fibrosis/fat necrosis distinguishing patients with/without XRCC1 399GIn. The mutation is toxic or protective when OR is higher or lower than 1, respectively. 


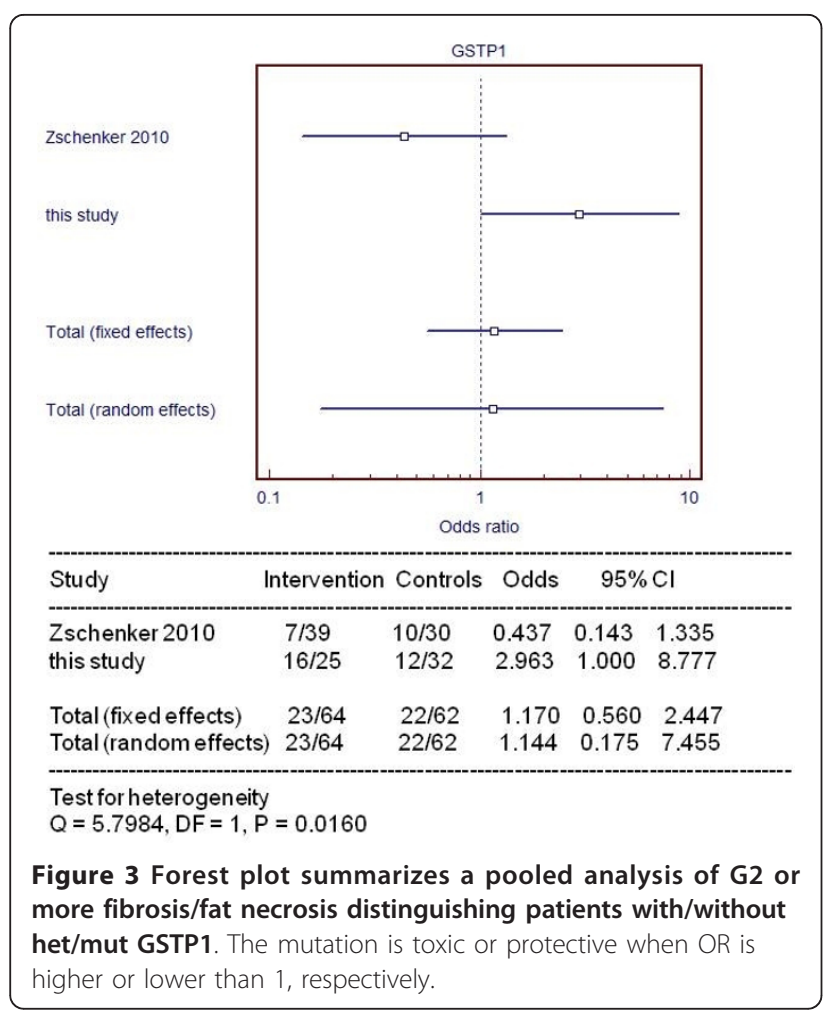

factor) [41], that is involved in over expression of TGF$\beta 1$ (Transforming Growth factor $\beta 1$ ) at sites of RTinduced injury. The critical role of TGF- $\beta 1$ in beginning, expansion and perseverance of fibrosis should be important for preventing/reducing the radiation-induced wound, also including loss of parenchymal cells and excess of fibrous tissue. Furthermore, TGF- $\beta 1$ modulates the activities of cytochine, TNF- $\alpha$ (Tumour Necrosis Factor alpha), basic fibroblast growth factor (bFGF), granulocyte macrofage colony-stimulating factor (GMCFS) IL-1, IL-4(interleukins) and connective tissue growth factor (CTGF) that are deregulated after radiation [42-45]. Thus, this figure suggests that GSTp1 could be indirectly correlated with the regulation of TGF- $\beta 1$ by the AP-1 path [46,47].

In accordance with our data, we speculate that the occurrence of fibrosis observed in our cohort of patients may be correlated to the altered regulation of TGF- $\beta 1$ induced by GSTP1 $105 \mathrm{Val}$ polymorphic variant. In this connection, it will be of interest to address this important issue in future studies evaluating the expression levels of TGF- $\beta 1$ in patients bearing GSTP1 polymorphism.

In this same cohort of patients, we also evaluated the effects of polymorphism encoding enzymes involved in

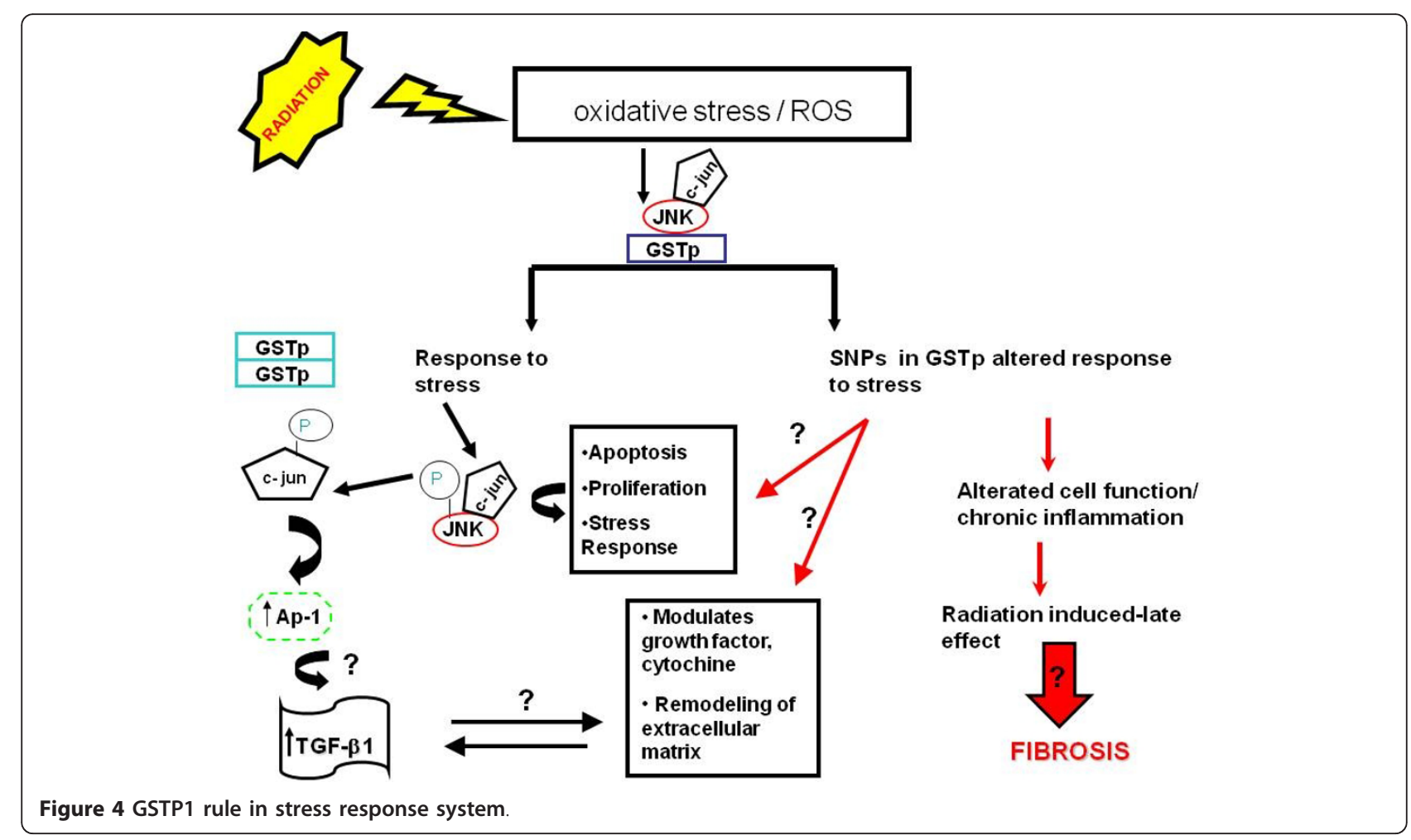


$D N A$ repair, such as $X R C C 1$ and $X R C C 3$, in relation to fibrosis or fat necrosis. In fact, the cellular pathways of DNA repair more involved in the response to radiation injury are $D S B R$ and $B E R$ In vitro and in vivo studies have shown that polymorphisms of genes involved in these two mechanisms of DNA repair may influence the cellular sensitivity to RT [48-50]. Our results showed no significant association between $\mathrm{XRCC} 3 \mathrm{C18067T}$ and radio-sensitivity in agreement with studies by Andreassen et al. and Chang-Claude et al. [51-53] in breast cancer patients or by Alsbeish et al. in head and neck cancer patients [54].

An association between wild type XRCC3 C18067 and an increased rate of late toxic effects, such as subcutaneous fibrosis, were found in breast cancer [55] and prostate [56].

No statistical significant association between XRCC1 $\mathrm{Arg} 399 \mathrm{Gln}$ and radio-sensitivity was found in our study, as well as in other studies $[17,19,57]$. However, Forest plot showed a behaviour as toxic agent of mut/het XRCC1 Arg399Gln in agreement with an increased rate of lung effects in non small cell lung cancer patients. [58].

Finally, no correlation was found between late toxicity mut/het XRCC3 A4541G and mut/het RAD51.

Our low correlation between incidence of G2 or more fibrosis or fat necrosis and alleles/patient is probably due to the low number of patients with G2 or more fibrosis or fat necrosis. Another issue to consider is that in comparison of other findings some differences are expected due to the types of adverse reactions studied, the length of follow-up for observing side effects, as well as, the additional patient-related factors.

\section{Conclusions}

The presence of some SNPs involved in DNA repair or response to oxidative stress seem to be able to predict late toxicity. This study, although affected by a limited number of patients, has a power of the study statistically sufficient to suggest that SNP in GSTP1 gene could be useful to predict late toxicity in $\mathrm{BC}$ patients who underwent SSPBI. Further data are needed to confirm these preliminary results. Moreover, future research will focus on the performance of many additional SNPs in other genes that are associated with the development of radiation toxicity.

\footnotetext{
Abbreviations

APBI: Accelerated partial breast irradiation; BER: Base excision repair; $B C$ : Breast cancer; BCS: Breast conserving surgery; CEU: Frequencies in European population; Cls: Confidence intervals; CMF: Cyclophosphamide methotrexate 5-fluorouracile; CTCAE: Common terminology criteria for adverse events; dNTP: Deoxynucleotide triphosphate; EC: Epirubicin cyclophosphamide; EDTA: Ethylenediaminetetracetic acid; EIC: Extended intraductal component; FEC: 5-fluorouracile epirubicin cyclophosphamide; GSTs: Glutathione-Stransferases; HR: Homologous recombination; ID: Identification; MVA:
}

Multivariate analysis; NCBI: National Center for Biotechnology Information; ORs: Odds ratios; PCR: Polymerase chain reaction; PBI: Partial breast irradiation; RT: Radiation therapy; rs: Reference sequence; ROS: Reactive oxygen species; SSPBI: Shot partial breast irradiation; SNPs: Single nucleotides polymorphisms; XRCC1: X-ray repair cross-complementation group 1; XRCC3: $X$-ray repair cross-complementation group 3; WBI: Whole breast irradiation; 3D-CRT: 3D conformal radiation therapy.

\section{Acknowledgements}

The Authors wish to thank Mrs. Tania Merlino for the English revision

\section{Author details}

'Laboratory of Pharmacokinetic/Pharmacogenomic, Regina Elena National Cancer Institute, Rome, Italy. ${ }^{2}$ Laboratory of Medical Physics and Expert Systems, Regina Elena National Cancer Institute, Rome, Italy. ${ }^{3}$ Department of Radiation Oncology, Regina Elena National Cancer Institute, Rome, Italy. ${ }^{4}$ Department of Oncology Juravinski Cancer Center, McMaster University Hamilton, Hamilton, ON, Canada. ${ }^{5}$ Department of Public Health, Harvard University, Boston, MA, USA. ${ }^{6}$ Translational Oncogenomic, Regina Elena National Cancer Institute, Rome, Italy.

\section{Authors' contributions}

FE, PP, SL conceived the study and obtained grant funding, coordination of the original study, coordinated genotyping efforts, supervised data analysis, and drafted the manuscript. VB, FF and GB participated in data management and statistical analysis, and in drafting the manuscript. GC and LB participated in the design of the original study, data collection and patient management, and in drafting the final manuscript. CG, MP, and BG participated in design of original study, and participated in drafting of final manuscript. All authors read and approved the final manuscript.

\section{Competing interests}

The authors declare that they have no competing interests.

Received: 22 December 2011 Accepted: 24 January 2012

Published: 24 January 2012

\section{References}

1. Veronesi U, Marubini E, Mariani L, Galimberti V, Luini A, Veronesi $P$, Salvadori B, Zucali R: Radiotherapy after breast-conserving surgery in small breast carcinoma: long-term results of a randomized trial. Ann Oncol 2001, 12:997-1003.

2. Fisher ER, Anderson S, Redmond C, Fisher B: Ipsilateral breast tumor recurrence and survival following lumpectomy and irradiation: pathological findings from NSABP protocol B-06. Semin Surg Oncol 1992, 8:161-166.

3. Veronesi U, Luini A, Del Vecchio M, Greco M, Galimberti V, Merson M, Rilke F, Sacchini V, Saccozzi R, Savio T, et al: Radiotherapy after breastpreserving surgery in women with localized cancer of the breast. $N$ Engl J Med 1993, 328:1587-1591.

4. Arthur DW, Vicini FA: Accelerated partial breast irradiation as a part of breast conservation therapy. J Clin Oncol 2005, 23:1726-1735.

5. Pinnarò P, Soriani A, Landoni V, Giordano C, Papale M, Marsella A, Marucci L, Arcangeli G, Strigari L: Accelerated hypofractionated radiotherapy as adjuvant regimen after conserving surgery for early breast cancer: interim report of toxicity after a minimum follow up of 3 years. J Exp Clin Cancer Res 2010, 29:9.

6. Bentzen SM, Yarnold JR: Reports of unexpected late side effects of accelerated partial breast irradiation-radiobiological considerations. Int J Radiat Oncol Biol Phys 2010, 77:969-973.

7. Hepel JT, Tokita M, MacAusland SG, et al: Toxicity of three-dimensional conformal radiotherapy for accelerated partial breast irradiation. Int $J$ Radiat Oncol Biol Phys 2009, 75:1290-1296.

8. Pinnarò $P$, Arcangeli $S$, Giordano $C$, Arcangeli G, Impiombato FA, Pinzi V, laccarino G, Soriani A, Landoni V, Strigari L: Toxicity and cosmesis outcomes after single fraction partial breast irradiation in early stage breast cancer. Radiat Oncol 2011, 6:155.

9. Denham JW, Hauer-Jensen M: The radiotherapeutic injury-a complex 'wound'. Radiother Oncol 2002, 63:129-145.

10. Riley P: Free radicals in biology: oxidative stress and the effects of ionizing irradiation. Int J Radiat Biol 1994, 65:27-33. 
11. Edvardsen H, Kristensen VN, Grenaker Alnaes Gl, Bøhn M, Erikstein B, Helland A, Børresen-Dale AL, Fosså SD: Germline glutathione S-transferase variants in breast cancer: relation to diagnosis and cutaneous long-term adverse effects after two fractionation patterns of radiotherapy. Int J Radiat Oncol Biol Phys 2007, 67:1163-1171.

12. Bentzen SM: Preventing or reducing late side effects of radiation therapy: radiobiology meets molecular pathology. Nat Rev Cancer 2006, 6:702-713

13. Yin Z, Ivanov VN, Habelhah $H$, Tew K, Ronai Z: Glutathione S-transferase $p$ elicits protection against $\mathrm{H} 2 \mathrm{O} 2$-induced cell death via coordinated regulation of stress kinases. Cancer Res 2000, 60:4053-4057.

14. Manevich Y, Feinstein SI, Fisher AB: Activation of the antioxidant enzyme 1-CYS peroxiredoxin requires glutathionylation mediated by heterodimerization with pi GST. Proc Natl Acad Sci USA 2004, 101:3780-3785

15. Wu Y, Fan $Y$, Xue $B$, Luo L, Shen J, Zhang $S$, Jiang $Y$, Yin Z: Human glutathione S-transferase P1-1 interacts with TRAF2 and regulates TRAF2-ASK1 signals. Oncogene 2006, 25:5787-5800.

16. Ambrosone CB, Tian C, Ahn J, Kropp S, Helmbold I, von Fournier D, Haase W, Sautter-Bihl ML, Wenz F, Chang-Claude J: Genetic predictors of acute toxicitiesrelated to radiation therapy following lump ectomy for breast cancer: a case-series study. Breast Cancer Res 2006, 8:R40.

17. Hoeijmakers JH: Genome maintenance mechanisms for preventing cancer. Nature 2001, 411:366-374.

18. Jeggo P, Lobrich M: Radiation-induced DNA damage responses. Radiat Prot Dosim 2006, 122:124-127.

19. Chistiakov DA, Voronova NV, Chistiakov PA: Genetic variations in DNA repair genes, radiosensitivity to cancer and susceptibility to acute tissue reactions in radiotherapy-treated cancer patients. Acta Oncologica 2008, 47:809-824.

20. Moullan N, Cox DG, Angele S, Romestaing P, Gerard JP, Hall J: Polymorphisms in the DNA Repair Gene XRCC1, Breast Cancer Risk, and Response to Radiotherapy. Cancer Epidemiol Biomarkers Prev 2003, 12:1168-1174.

21. Mango Mangoni M, Bisanzi S, Carozzi F, Sani C, Biti G, Livi L, Barletta E, Costantini AS, Gorini G: Association between genetic polymorphisms in the XRCC1, XRCC3, XPD, GSTM1, GST1, MSH2, MLH1, MSH3, and MGMT genes and radiosensitivity in breast cancer patients. Int J Radiat Oncol Biol Phys 2011, 81:52-58.

22. Popanda O, Tan XL, Ambrosone CB, Kropp S, Helmbold I, von Fournier D, Haase W, Sautter-Bihl ML, Wenz F, Schmezer P, Chang-Claude J: Genetic polymorphisms in the DNA double-strand break repair genes XRCC3, XRCC2, and NBS1 are not associated with acute side effects of radiotherapy in breast cancer patients. Cancer Epidemiol Biomarkers Prev 2006, 15:1048-1050.

23. Chang-Claude J, Popanda O, Tan XL, Kropp S, Helmbold I, von Fournier D, Haase W, Sautter-Bihl ML, Wenz F, Schmezer P, Ambrosone CB: Association between polymorphisms in the DNA repair genes,XRCC1, APE1, and XPD and acute side effects of radiotherapy in breast cancer patients. Clin Cancer Res 2005, 11:4802-4809.

24. Travis EL: Genetic susceptibility to late normal tissue injury. Semin Radiat Oncol 2007, 17:14.

25. Morgan JL, Holcomb TM, Morrissey RW: Radiation reaction in ataxia telangiectasia. Am J Dis Child 1968, 116:557-558.

26. laccarino G, Pinnaro P, Landoni V, Marzi S, Soriani A, Giordano C, Arcangeli S, Benassi M, Arcangeli G: Single fraction partial breast irradiation in prone position. J Exp Clin Cancer Res 2007, 26:543-552.

27. Bruzzaniti $V$, Abate A, Pedrini M, Benassi M, Strigari L: IsoBED: a tool for automatic calculation of biologically equivalent fractionation schedules in radiotherapy using IMRT with a simultaneous integrated boost (SIB) technique. J Exp Clin Cancer Res 2011, 30:52

28. Creton G, Benassi M, Di Staso M, Ingrosso G, Giubilei C, Strigari L: The time factor in oncology: consequences on tumour volume and therapeutic planning. J Exp Clin Cancer Res 2006, 25:557-573.

29. Cividalli A, Creton G, Ceciarelli F, Strigari L, Tirindelli Danesi D, Benassi M: Influence of time interval between surgery and radiotherapy on tumor regrowth. J Exp Clin Cancer Res 2005, 24:109-116.

30. Strigari $L, D^{\prime}$ Andrea $M$, Abate $A$, Benassi $M$ : A heterogeneous dose distribution in simultaneous integrated boost: the role of the clonogenic cell density on the tumor control probability. Phys Med Biol 2008, 7:5257-5273
31. CTCAE, version 3.0. [http://ctep.cancer.gov/protocoldevelopment/ electronic_applications/docs/ctcaev3.pdf].

32. Lövely K, Fodor J, Major T, Szabó E, Orosz Z, Sulyok Z, Jánváry L, Fröhlich G, Kásler M, Polgár C: Fat necrosis after partial-breast irradiation with brachytherapy or electron irradiation versus standard whole-breast radiotherapy: 4-year results of a randomized trial. Int J Radiat Oncol Biol Phys 2007, 69:724-731.

33. Marsh S, King CR, Garsa AA, McLeod HL: Pyrosequencing of clinically relevant polymorphisms. Methods Mol Biol 2005, 311:97-114.

34. Falvo E, Strigari L, Citro G, Giordano C, Arcangeli S, Soriani A, D'Alessio D, Muti P, Blandino G, Sperduti I, Pinnarò P: Dose and polymorphic genes $x r c c 1, x r c c 3$, gst play a role in the risk of developing erythema in breast cancer patients following single shot partial breast irradiation after conservative surgery. BMC Cancer 2011, 11:291.

35. Bartelink H, Horiot JC, Poortmans PM, Struikmans H, Van den Bogaert W, Fourquet A, Jager JJ, Hoogenraad WJ, Oei SB, Wárlám-Rodenhuis CC, Pierart $\mathrm{M}$, Collette $\mathrm{L}$ : Impact of a higher radiation dose on local control and survival in breast-conserving therapy of early breast cancer: 10-year results of the randomized boost versus no boost EORTC 22881-10882 trial. J Clin Oncol 2007, 25:3259-3265.

36. Rosenstein BS: Identification of SNPs associated with susceptibility for development of adverse reactions to radiotherapy. Pharmacogenomics 2011, 12:267-275

37. Adler V, Pincus MR: Effector peptides from glutathione-S-transferase-pi affect the activation of jun by jun-N-terminal kinase. Ann Clin Lab Sci 2004, 34:35-46.

38. Holley SL, Fryer AA, Haycock JW, Grubb SE, Strange RC, Hoban PR Differential effects of glutathione S-transferase pi (GSTP1) haplotypes on cell proliferation and apoptosis. Carcinogenesis 2007, 11:2268-2273.

39. Zschenker O, Raabe A, Boeckelmann IK, Borstelmann S, Szymczak S, Wellek S, Rades D, Hoeller U, Ziegler A, Dikomey E, Borgmann K: Association of single nucleotide polymorphisms in ATM, GSTP1, SOD2, TGFB1, XPD and XRCC1 with clinical and cellular radiosensitivity. Radiother Oncol 2010, 97:26-32.

40. Kuptsova N, Chang-Claude J, Kropp S, Helmbold I, Schmezer P, von Fournier D, Haase W, Sautter-Bihl ML, Wenz F, Onel K, Ambrosone CB: Genetic predictors of long-term toxicities after radiation therapy for breast cancer. Int J Cancer 2008, 122:1333-1339.

41. Townsend DM: S-glutathionylation: indicator of cell stress and regulator of the unfolded protein response. Mol Interv 2007, 7:313-324.

42. Bentzen SM: Preventing or reducing late side effects of radiation therapy: radiobiology meets molecular pathology. Nat Rev Cancer 2006, 6:702-713.

43. Martin $M$, Lefaix $J$, Pinton $P$, Crechet $F$, Daburon F: Temporal modulation of TGF-beta 1 and beta-actin gene expression in pig skin and muscular fibrosis after ionizing radiation. Radiat Res 1993, 134:63-70.

44. O'Sullivan B, Levin W: Late radiation-related fibrosis: pathogenesis, manifestations, and current management. Semin Radiat Oncol 2003, 13:274-289.

45. Zhao W, Diz DI, Robbins ME: Oxidative damage pathways in relation to normal tissue injury. Br J Radiol 2007, 80:23-31.

46. Tew KD, Ronai Z: GST function in drug and stress response. Drug Resist Updat 1999, 2:143-147.

47. Martin M, Vozenin MC, Gault N, Crechet F, Pfarr CM, Lefaix JL: Coactivation of AP-1 activity and TGF-b1 gene expression in the stress response of normal skin cells to ionizing radiation. Oncogene 1997, 15:981-989.

48. Andreassen CN, Alsner J, Overgaard J: Does variability in normal tissue reactions after radiotherapy have a genetic basis-where and how to look for it? Radiother Oncol 2002, 64:131-140.

49. West CM, Elliott RM, Burnet NG: The genomics revolution and radiotherapy. Clin Oncol 2007, 19:470-480.

50. Filippi AR, Franco P, Ricardi U: Is clinical radiosensitivity a complex genetically controlled event? Tumori 2006, 92:87-91.

51. Andreassen CN, Alsner J, Overgaard M, Sorensen FB, Overgaard J: Risk of radiation-induced subcutaneous fibrosis in relation to single nucleotide polymorphisms in TGFB1, SOD2, XRCC1, XRCC3, APEX and ATM-a study based on DNA from formalin fixed paraffin embedded tissue samples. Int J Radiat Biol 2006, 82:577-586.

52. Andreassen CN, Alsner J, Overgaard J, Herskind C, Haviland J, Owen R, Homewood J, Bliss J, Yarnold J: TGFB1 polymorphisms are associated 
with risk of late normal tissue complications in the breast after radiotherapy for early breast cancer. Radiother Oncol 2005, 75:18-21.

53. Chang-Claude J, Ambrosone CB, Lilla C, Kropp S, Helmbold I, von Fournier D, Haase W, Sautter-Bihl ML, Wenz F, Schmezer P, Popanda O: Genetic polymorphisms in DNA repair and damage response genes and late normal tissue complications of radiotherapy for breast cancer. $\mathrm{Br} \mathrm{J}$ Cancer 2009, 100:1680-1686.

54. Alsbeih G, Al-Harbi N, Al-Hadyan K, El-Sebaie M, Al-Rajhi N: Association between normal tissue complications after radiotherapy and polymorphic variations in TGFB1 and XRCC1 genes. Radiat Res 2010, 173:505-511.

55. Andreassen CN, Alsner J, Overgaard M, Overgaard J: Prediction of normal tissue radiosensitivity from polymorphisms in candidate genes. Radiother Oncol 2003, 69:127-135.

56. Damaraju S, Murray D, Dufour J, et al: Association of DNA repair and steroid metabolism gene polymorphisms with clinical late toxicity in patients treated with conformal radiotherapy for prostate cancer. Clin Cancer Res 2006, 12:2545-2554.

57. Giotopoulos G, Symonds RP, Foweraker K, Griffin M, Peat I, Osman A, Plumb M: The late radiotherapy normal tissue injury phenotypes of telangiectasia, fibrosis and atrophy in breast cancer patients have distinct genotype-dependent causes. Br J Cancer 2007, 96:1001-1007.

58. Yin M, Liao Z, Liu Z, Wang LE, Gomez D, Komaki R, Wei Q: Functional Polymorphisms of Base Excision Repair Genes XRCC1 and APEX1 Predict Risk of Radiation Pneumonitis in Patients with Non-Small Cell Lung Cancer Treated with Definitive Radiation Therapy. Int I Radiat Oncol Biol Phys 2011, 81:e67-e73.

doi:10.1186/1756-9966-31-7

Cite this article as: Falvo et al: SNPs in DNA repair or oxidative stress genes and late subcutaneous fibrosis in patients following single shot partial breast irradiation. Journal of Experimental \& Clinical Cancer Research $201231: 7$

\section{Submit your next manuscript to BioMed Central and take full advantage of:}

- Convenient online submission

- Thorough peer review

- No space constraints or color figure charges

- Immediate publication on acceptance

- Inclusion in PubMed, CAS, Scopus and Google Scholar

- Research which is freely available for redistribution

Submit your manuscript at www.biomedcentral.com/submit 